\title{
Faculty Work Engagement and Teaching Effectiveness in a State Higher Education Institution
}

\author{
Sanny Fernandez
}

\begin{tabular}{l} 
ARTICLE INFO \\
\hline Article History: \\
Received 29.12.2019 \\
Received in revised form \\
21.08.2020 \\
Accepted \\
Available online 01.01.2021
\end{tabular}

\begin{abstract}
This survey-correlational research determined the faculty work engagement and teaching effectiveness. The antecedent variables were length of teaching experience, academic rank, educational qualification and college affiliation. The independent variable was work engagement and teaching effectiveness was the dependent variable. The study was conducted among the 139 randomly selected faculty in a state institution of higher learning in the province of Iloilo. Two adopted, validated and pilot tested data gathering instruments were used - the Employee Engagement Survey Question (Margolis, 2018) and Teacher Effectiveness Questionnaire (Mishra, 2012). Statistical tools were means, standard deviations, one-way ANOVA, and the Pearson's r. Significance level for all inferential tests was set at .05 alpha. Study results revealed the faculty were engaged in their work and were effective as teachers. The faculty did not differ significantly in their work engagement when they were classified according to length of teaching experience, academic rank, educational qualification and college affiliation. A significant difference was noted in teaching effectiveness among the faculty classified according to educational qualification but no significant differences when they were classified according to length of teaching experience, academic rank and and college affiliation. A significant relationships existed among the faculty work engagement, and teaching effectiveness.
\end{abstract}

(C) IJERE. All rights reserved

Keywords: ${ }^{1}$

Education, Faculty, work engagement,teaching effectiveness, survey-correlational.

\section{INTRODUCTION}

Over the last forty years there have been substantial changes in the structure of professional employment in higher education, with implications for fostering faculty engagement on a broad scale. Moreover, current policy pressures, and the institutional practices create a challenge for colleges and universities to increase attainment and quality (Rhoades, 2012). Work engagement is a positive, fulfilling, work-related state of mind that is characterized by vigor, dedication, and absorption. Employees reporting higher work engagement tend to be more satisfied, productive and show increased job longevity. As such, institutions benefit both financially and educationally by having faculty who are engaged with the academic community (Schaufeli and Bakker, 2010). The success of any college or university depends in large part on the effectiveness of its teaching community. As the front line in delivering quality education, faculty members are a key determinant in whether or not an institution lives up to the needs and expectations of its students. Accordingly, faculty members need to feel that they're an essential, integrated element in the institution at which they work (Cherwin, 2016). According to Borkar (2013), the effectiveness of the educational system largely depends upon the effective teachers. Paolini (2015) mentioned that "exceptional instructors are culturally sensitive, respectful, passionate, and charismatic. They challenge students to work to their potential by setting high, yet reasonable expectations, emphasizing open communication, and asking higher-order thinking questions that stimulate discussion. Barry (2010) argues that teaching effectiveness can be understood by examining what effective teachers know and do in their daily professional practice.

This study is connected with the theory of employee engagement which states that leaders of an organization must ensure that all their staff members are fully engaged, that they are fully switched on at their jobs. Being engaged simply means that you are fully involved and interested in the work so that it really holds your attention and inspires you to do your bes (Awaragroup.com 2012). This study is linked to Harris and Rutledge (2007) which concluded that the predictors of teacher quality and effectiveness are cognitive ability, personality attributes and educational background.

\footnotetext{
${ }^{1}$ Email: sannyfernandez0@gmail.com, lloilo State College of Fisheries
} ORCID No. 0000-0003-0024-4542 
In this globalizing world in which we are experiencing many changes in science and technology, the importance of education is growing and it is necessary that well equipped teachers are trained for highquality education (Sahan, 2016). It is observable that faculty in higher education are grappling with the challenges of the multiple roles they played in instruction, reseach and extension. The demand in accreditition likewise sometimes eat up instructional time. These crossroads teachers are facing may affect their teaching performance. How engaged are the faculty in a state institution of higher learning? How effective are their teaching? These questions need to be answered, hence this study.

\section{Statement of the Problem and the Hypotheses}

This study aims to ascertain the work engagement and teaching effectiveness among the faculty in state institutions of higher learning in the province of Iloilo.

$\begin{array}{lll}\text { ANTECEDENT } & \text { INDEPENDENT } & \text { DEPENDENT } \\ \text { VARIABLE } & \text { VARIABLE } & \text { VARIABLE }\end{array}$

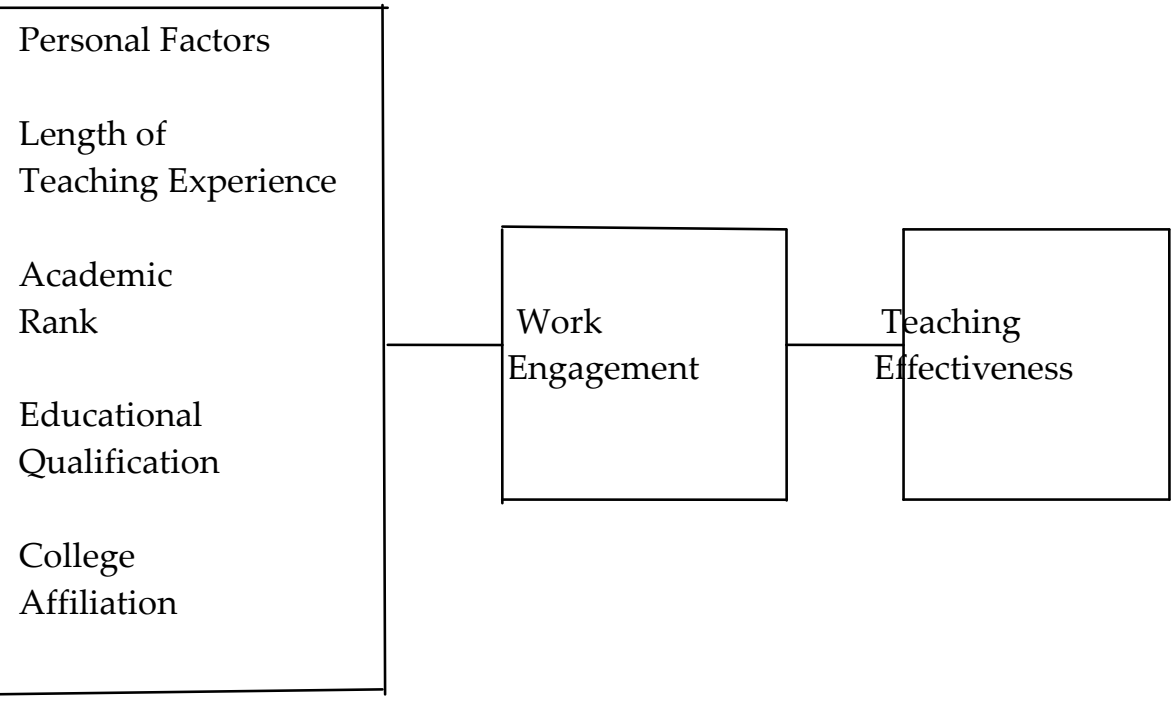

Figure 1. Faculty's teaching effectiveness as related to work engagement and certain identified personal factors

Specifically, the study sought answers to the following problem statement:

1) Work engagement of the faculty taken as an entire group and when classified according to a) length of teaching experience, b) academic rank, c) educational qualification, and d) college affiliation. 2) Effectiveness among the faculty taken as an entire group and when classified according to a) length of teaching experience, b) academic rank, c) educational qualification, and d) college affiliation. 3) Significant differences in work engagement among the faculty classified according to a) length of teaching experience, b) academic rank, c) educational qualification, and d) college affiliation. 4) Significant differences in teaching effectiveness among the faculty classified according to a) length of teaching experience, b) academic rank, c) educational qualification, and d) college affiliation. 5) Significant relationships between work engagementand teaching effectiveness

In view of the aforementioned problems, the following hypothesis was tested:

1) There are no significant differences in the work engagement among the faculty classified according to a) length of teaching experience, b) academic rank, c) educational qualification, and d) college affiliation. 2) There are no significant differences in teaching effectiveness among the faculty classified according to a) length of teaching experience, b) academic rank, c) educational qualification, and d) college affiliation. 3)There are no significant relationships between faculty work engagement and teaching effectiveness. 


\section{PURPOSE OF THE STUDY AND RESEARCH DESIGN}

This study aimed to determine the work engagement as related to teaching effectiveness in a state institutions of higher learning in the province of Iloilo, Philippines.

The survey-correlational method of research was employed in this investigation. Fraenkel and Wallen (2003) explain that the major purpose of survey research is to describe the characteristics of a population. In essence, information is collected from a group of people in order to describe some aspects of characteristics (such as abilities, opinion, attitudes, beliefs, and or knowledge) of the population of which that group is part. In correlation research, which is sometimes called associative research, is the relationships among two or more variables although investigations of more than two variables are common.

In this investigation, the dependent variable was the teaching effectiveness and the independent variables was work engagement. The antecedent variables were length of teaching experience, academic rank, educational qualification and college affiliation.

\section{METHOD}

\section{Participants}

The participants of the study were 139 randomly selected full time faculty in a state institution of higher learning. The participants were classified according to their length of teaching experience, academic rank, educational qualification, and college affiliation.

They were further categorized into 10 years and below, 11-20 and above 20 years for the length of teaching experience; instructor, assistant professor, associate professor and professor for academic rank; baccalaureate, master's and doctorate degree for educational qualification; and management, teacher education, information technology, agriculture, and maritime for college affiliation. This is reflected in table 1.

Table 1. Distribution of the participants

\begin{tabular}{|c|c|c|}
\hline Category & $\mathrm{f}$ & $\%$ \\
\hline Entire group & 139 & 10 \\
\hline \multicolumn{3}{|l|}{ Length of teaching experience } \\
\hline 10 years and below & 37 & 26 \\
\hline 11 to 20 years & 47 & 34 \\
\hline Above 20 years & 55 & 40 \\
\hline \multicolumn{3}{|l|}{ Academic rank } \\
\hline Instructor I-III & 34 & 24 \\
\hline Assistant Professor I-IV & 57 & 41 \\
\hline Associate Professor I-V & 43 & 31 \\
\hline Professor I-VI & 5 & 4 \\
\hline \multicolumn{3}{|l|}{ Educational qualification } \\
\hline Baccalaureate Degree & 5 & 4 \\
\hline Master's Degree & 71 & 51 \\
\hline Doctorate Degree & 63 & 45 \\
\hline \multicolumn{3}{|l|}{ College affiliation } \\
\hline Management & 25 & 18 \\
\hline Teacher Education & 60 & 43 \\
\hline Information Technology & 25 & 18 \\
\hline Agriculture & 22 & 16 \\
\hline Maritime & 7 & 5 \\
\hline
\end{tabular}

\section{Data-gathering Instrument}

To gather the data needed, the researcher used two adopted, validated and pilot tested data-gathering instruments the Employee Engagement Survey Question (Margolis, 2018) and the Teacher Effectiveness Questionnaire (Mishra, 2012). 
The Employee Engagement Survey Question is composed of 33 items. It is answerable by SD - Strongly disagree, D - Disagree, N -Neutral, A - Agree and SA - Strongly disagree. Each followed by number 1, 2, 3, 4,5 in continuum from "Strongly disagree" to "Strongly agree". by the item.

"Strongly agree" means that the participant was extremely in favor of the idea or situation conveyed

"Agree" means that the participant was in favor of the idea or situation conveyed by the item.

"Neutral" means that the participant was neither favor nor in favor of the idea conveyed in the item.

"Disagree" means that the participant was not in favor of the idea or situation conveyed by the item.

"Strongly disagree" means that the participant was extremely not in favor of the idea or situation conveyed in the item.

For scoring purposes, each response is given an equivalent weight as follows:

Table 2. Weight of responses

\begin{tabular}{lc}
\hline Response & Weight \\
\hline Strongly disagree & 1 \\
Disagree & 2 \\
Neutral & 3 \\
Agree & 4 \\
Strongly agree & 5 \\
\hline
\end{tabular}

To interpret the obtained means, the following scale of means and corresponding interpretation were used:

Table 3. Scale of means and interpretations

\begin{tabular}{cl}
\hline Range of Mean Scores & Interpretation \\
\hline $4.51-5.0$ & Actively engaged \\
$3.51-4.50$ & Engaged \\
$2.51-3.50$ & Barely engaged \\
$1.51-2.50$ & Disengaged \\
$1.0-1.50$ & Actively disengaged \\
\hline
\end{tabular}

Actively engaged. Actively engaged faculty have consistently high levels of performance and a drive for efficiency. They have a very clear understanding about the desired outcomes of their roles. They have emotional commitment to what they do, to their organization, work group,and job. Thus, actively engaged faculty have been likely identified as high-potential employees and feature prominently in their organization's succession planning process.

Engaged. Engaged faculty have high levels of performance and a drive for efficiency. They have a clear understanding about the desired outcomes of their roles. They have emotional commitment to what they do, to their organization, work group, and job.

Barely engaged. Barely engaged faculty view their jobs as an exchange of time for a paycheck. They arrive and leave on time, take their breaks, never volunteer for extra works or projects, and do little else in between beyond the minimal effort. They show little passion or creativity for their jobs and go through the motions. Barely engaged faculty may have been actively engaged employee at one time. Somewhere along the way, though, they became disengaged because of a lack of career growth, promotion, a perception of salary inequity, job dislike, or distrust in their immediate supervisor and senior management.

Disengaged.Disengaged faculty are damaging employees in the workplace. They are unhappy and let that unhappiness show in words, attitudes and actions.

Actively disengaged.Actively disengaged faculty are the most damaging employees in the workplace. They are disappointed and let that disappointment show in words, attitudes and actions. They undermine 
the performance of others by constantly voicing their displeasure and listing the many reasons why they are so miserable in their jobs.

The Teacher Effectiveness Questionnaire is composed of 48 items. Participants were asked to circle corresponding to their choice. It is answerable by SD - Strongly disagree, D - Disagree, U - Undecided, A Agree and SA-Strongly disagree.

"Strongly Agree" means that the participant was extremely in favor of the idea or situation conveyed by the item.

"Agree" means that the participant was in favor of the idea or situation conveyed by the item.

"Undecided" means that the participant was neither favor nor in favor of the idea conveyed in the item.

"Disagree" means that the participant was not in favor of the idea or situation conveyed by the item.

"Strongly disagree" means that the participant was extremely not in favor of the idea or situation conveyed in the item.

For scoring purposes, each response is given an equivalent weight as follows:

Table 4. Weight of responses

\begin{tabular}{lc}
\hline Response & Weight \\
\hline Strongly disagree & 1 \\
Disagree & 2 \\
Undecided & 3 \\
Agree & 4 \\
Strongly agree & 5 \\
\hline
\end{tabular}

To interpret the obtained means, the following scale of means and corresponding interpretation were used:

Table 5. Scale of means and interpretations

\begin{tabular}{cl}
\hline Range of Mean Scores & Interpretation \\
\hline $4.51-5.0$ & Absolutely effective \\
$3.51-4.50$ & Effective \\
$2.51-3.50$ & Moderately effective \\
$1.51-2.50$ & Ineffective \\
$1.0-1.50$ & Absolutely ineffective \\
\hline
\end{tabular}

\footnotetext{
"Absolutely effective" means action which was very sufficient to achieve a purpose.

"Effective" means action which was sufficient to achieve a purpose.

"Moderately effective" means action which was moderately sufficient to achieve a purpose.

"Ineffective" means action which was insufficient to achieve a purpose.

"Absolutely ineffective" means action which was very insufficient to achieve a purpose.
}

\section{Validity and realibility of the data gathering instruments.}

The two (2) data-gathering instruments were subjected to validity and reliability testing.These data gathering instruments were pilot tested to 30 faculty in another state institution of higher learning, to ensure comparability of the participants. Results of the pilot test were subjected to validity and realibilty assuring the administrability and acceptability of the data-gathering instruments for the purpose intended. 
Table 6. Results of the factor analyses and reliability tests

\begin{tabular}{lcc}
\hline & \multicolumn{2}{c}{ Range of } \\
& Factor Loads & Reliability \\
& Cronbach alpha \\
\hline For Employee Engagement Survey Question & $.531-.926$ & .922 \\
& & \\
For Teacher Effectiveness Questionnaire & $.540-.821$ & .941 \\
\hline
\end{tabular}

According to Alicias (1986), there is no hard and fast rule for factor loading, except that, which is arbitrarily determined by the researcher. However, a factor loading of +.50 or higher is commonly used. Following Alicias, factor loads of all the items in the three data-gathering instruments qualified for the criterion and hence, were considered. Fraenkel and Wallen (1988), for a research instrument to be reliable, it should have at least a reliability coefficient of .70 .

\section{PROCEDURE}

Permission to conduct the study was secured from the SUC President. Upon approval, the research instruments were administered to the target participants. The obtained data were tallied, tabulated, computer-processed, analyzed and interpreted.

\section{DATA ANALYSIS PROCEDURE}

The statistics used in this study are frequency count, percentage analysis, means, standard deviation, ANOVA and Pearson's $r$.

\section{RESULTS}

\section{Descriptive Data Analysis}

Faculty work engagement . Data in Table 7 show that over-all, the faculty were engaged $(M=4.20$, $S D=.62)$ in their work and in the following categories, length of teaching experience, 10 years and below $(M=4.15, S D=.52), 11$ to 20 years $(M=4.15, S D=.75)$, above 20 years $(M=4.29, S D=.56)$, academic rank, instructor $(M=4.09, S D=.71)$, assistant professor $(M=4.20, S D=.65)$, associate professor $(M=4.30, S D=$ $.54)$, professor $(M=4.22, S D=.22)$, educational qualification, baccalaureate degree $(M=4.12, S D=.57)$, master's degree $(M=4.12, S D=.67)$, doctorate degree $(M=4.30, S D=.56)$ college affiliation, management $(M=4.37, S D=.60)$, teacher education $(M=4.26, S D=.70)$, information technology $(M=4.00, S D=.51)$, agriculture $(M=4.12, S D=.54)$, and maritime $(M=4.10, S D=.60)$.

Shuck's (2011) review of work engagement concluded that the construct remains in a state of evolution, with disciplinary bridges needed between disparate communities of research. As educational psychologist, he questioned the fit of business-oriented work engagement models and measures to educational contexts, and see a clear need for a context-specific engagement measure tailored to the work performed by teachers.

The primary factors that drive faculty engagement are in the areas of career track (nature of appointment, specialization, and rewards), access to resources (financial support and staff support), control of teaching and research (course coordinator and department heads), and interest and preparation for community engagement (travel and interaction), (Sobrero \& Jayaratne, 2014). 
Table 7. Degree of Faculty Work Engagement

\begin{tabular}{|c|c|c|c|}
\hline Category & SD & $\mathbf{M}$ & Description \\
\hline Entire Group & 0.62 & 4.20 & Engaged \\
\hline \multicolumn{4}{|c|}{ Length of Teaching Experience } \\
\hline 10 years and below & 0.52 & 4.15 & Engaged \\
\hline 11 to 20 years & 0.75 & 4.15 & Engaged \\
\hline Above 20 years & 0.56 & 4.29 & Engaged \\
\hline \multicolumn{4}{|l|}{ Academic Rank } \\
\hline Instructor & 0.71 & 4.09 & Engaged \\
\hline Assistant Professor & 0.65 & 4.20 & Engaged \\
\hline Associate Professor & 0.54 & 4.30 & Engaged \\
\hline Professor & 0.22 & 4.22 & Engaged \\
\hline \multicolumn{4}{|l|}{ Educational Qualification } \\
\hline Baccalaureate Degree & 0.57 & 4.17 & Engaged \\
\hline Master's Degree & 0.67 & 4.12 & Engaged \\
\hline Doctorate Degree & 0.56 & 4.30 & Engaged \\
\hline \multicolumn{4}{|l|}{ College Affiliation } \\
\hline Management & 0.60 & 4.37 & Engaged \\
\hline Teacher Education & 0.70 & 4.26 & Engaged \\
\hline Information Technology & 0.51 & 4.00 & Engaged \\
\hline Agriculture & 0.54 & 4.12 & Engaged \\
\hline Maritime & 0.60 & 4.10 & Engaged \\
\hline
\end{tabular}

Note: 4.51-5.0 - Actively engaged; 3.51-4.50 - Engaged; 2.51 -3.50 - Barely engaged; 1.51-2.50 - Disengaged; 1.0-1.50 - Actively disengaged

Teaching effectiveness . Data inTable 8 show that over-all, the faculty were effective $(M=4.19, S D=$ .45) in their teaching and in the following categories, length of teaching experience, 10 years and below $(M=$ $4.13, S D=.33)$, 11 to 20 years $(M=4.18, S D=.54)$, above 20 years $(M=4.24, S D=.43)$, academic rank, instructor $(M=4.02, S D=.56)$, assistant professor $(M=4.26, S D=.38)$, associate professor $(M=4.25, S D=$ $.42)$, professor $(M=4.14, S D=.26)$, educational qualification, baccalaureate degree $(M=4.18, S D=.36)$, master's degree $(M=4.10, S D=.52)$, and doctorate degree $(M=4.19, S D=.49)$, college affiliation, management $(M=4.33, S D=.40)$, and teacher education $(M=4.21, S D=.52)$ information technology $(M=$ $4.10, S D=.32)$, agriculture $(M=4.09, S D=.44)$, and maritime $(M=4.18, S D=.33)$.

In reviewing the literature related to teacher quality models, Harris and Rutledge (2007) have concluded that the predictors of teacher quality and effectiveness are cognitive ability, personality attributes, and educational background. Contemporary teachers in the 21st century are geared towards adapting new teaching theories and external policies and issues. As the policies keep changing and becoming uncertain at times, it is important that teachers make fast and good decisions in their teaching instructions.

Evans (2006) argued that effective teaching is synonymous with teaching effectiveness and has been defined in three basic ways. These include definitions in terms of teachers' personalities teacherpupil interactions, and teachers' impact on pupil's behaviour. The presage, process, and product aspects of teaching are represented in these definitions very well. The presage and process aspects of teaching bear direct relationship to teachers' personalities and teacher-pupil interactions. Similarly, the product aspect bears direct relationship to teacher impact on pupil's behaviour. He also defined that teaching effectiveness as a manifestation of knowledge of content, skills in lesson presentation and creating desirable atmosphere for learning. 
Table 8. Level of teaching effectiveness

\begin{tabular}{llll}
\hline Category & SD & M & Description \\
\hline Entire Group & 0.45 & 4.19 & Effective \\
Length of Teaching Experience & & & \\
10 years and below & 0.33 & 4.13 & Effective \\
11 to 20 years & 0.54 & 4.18 & Effective \\
Above 20 years & 0.43 & 4.24 & Effective \\
& & & \\
Academic Rank & & & \\
Instructor & 0.56 & 4.02 & Effective \\
Assistant Professor & 0.38 & 4.26 & Effective \\
Associate Professor & 0.42 & 4.25 & Effective \\
Professor & 0.26 & 4.14 & Effective \\
Educational Qualification & & & \\
Baccalaureate Degree & 0.36 & 4.18 & Effective \\
Master's Degree & 0.52 & 4.10 & Effective \\
Doctorate Degree & 0.49 & 4.19 & Effective \\
& & & \\
College Affiliation & & & Effective \\
Management & 0.40 & 4.33 & Effective \\
Teacher Education & 0.52 & 4.21 & Effective \\
Information Technology & 0.32 & 4.10 & Effective \\
Agriculture & 0.44 & 4.09 & \\
Maritime & 0.33 & 4.18 & \\
\hline
\end{tabular}

Note: 4.51-5.0 - absolutely effective; 3.41-4.50 - Effective; 2.51-3.50 - Moderately effective; 1.81-2.60 - Ineffective; 1.0-1.50 - Absolutely ineffective

\section{Inferential Data Analysis}

Differences in faculty engagement. The One-way ANOVA results in Table 9 revealed that no significant differences existed in work engagement among the faculty grouped according to length of teaching experience, $F(2,136)=.819, p>.05$; academic rank $F(3,135)=.691, p>.05$, educational qualification, $F$ $(2,136)=1.480, p>.05$; and college affiliation, $F(4,134)=1.395, p>.05$.

Yen, et al. (2012) conducted a study of the predictive relationships between faculty engagement, learner satisfaction and outcomes in multiple learning delivery Modes. This study assessed the predictive relationships between faculty engagement, learner satisfaction, and outcomes across multiple learning delivery modes (LDMs). Participants were enrolled in courses with the options of three learning delivery modes: face-to-face, satellite broadcasting, and live video-streaming. The predictive relationship between faculty engagement and student satisfaction remained constant across the three learning delivery mode groups. In addition, faculty engagement was an effective predictor for learner satisfaction, regardless of LDM. Similarly, the predictive relationship between faculty engagement and learning outcomes as measured by final grades remained constant. The results also suggested that an increase in the faculty engagement score was accompanied by an increased probability of obtaining a better course final grade.

The primary factors that drive faculty engagement are in the areas of career track (nature of appointment, specialization, and rewards), access to resources (financial support and staff support), control of teaching and research (course coordinator and department heads), and interest and preparation for community engagement (travel and interaction) (Sobrero \& Jayaratne, 2014). 
Table 9. One-Way ANOVA results for differences in work engagement among the faculty grouped according to certain identified categories

\begin{tabular}{llllll}
\hline $\begin{array}{l}\text { Sources of } \\
\text { Variation }\end{array}$ & $\begin{array}{l}\text { Sum of } \\
\text { Squares }\end{array}$ & df & $\begin{array}{l}\text { Mean } \\
\text { Square }\end{array}$ & $F$ & Sig. \\
\hline
\end{tabular}

Length of Teaching Experience

$\begin{array}{lccccc}\text { Between Groups } & 0.632 & 2 & 0.316 & 0.819 & 0.443 \\ \text { Within Groups } & 52.489 & 136 & 0.386 & & \\ \text { Total } & 53.121 & 138 & & & \end{array}$

Academic Rank

Between Groups

0.803

30.268

Within Groups

52.318

$135 \quad 0.388$

0.691

0.559

Total

53.121

138

Educational Qualification

\begin{tabular}{lccccc} 
Between Groups & 1.132 & 2 & 0.566 & 1.480 & 0.231 \\
Within Groups & 51.989 & 136 & 0.382 & & \\
Total & 53.121 & 138 & & & \\
& & & & & \\
College Affiliation & & & & & \\
Between Groups & 2.123 & 4 & 0.531 & 1.395 & 0.239 \\
Within Groups & 50.998 & 134 & 0.381 & & \\
Total & 53.121 & 138 & & & \\
\hline
\end{tabular}

Differences in faculty teaching effectiveness. The One-Way ANOVA results in Table 10 reveal that significant differences existed in teaching effectiveness among the faculty classified according to educational qualification, $F(2,136)=5.793, p<.05$. Employing the post hoc test using Scheffé test it was revealed that faculty with doctorates $(M=4.35)$ were significantly more effective compared with those with master's degree $(M=3.98)$.

However, the One-way ANOVA results in Table 10, revealed that no significant differences were noted in teaching effectiveness among the faculty grouped according to length of teaching experience, $F(2,136)=$ $.768, p>.05$; academic rank $F(3,135)=2.552, p>.05$; and college affiliation, $F(4,134)=1.175, p>.05$.

This support the study of Harris and Rutledge (2007) which concluded that the predictors of teacher quality and effectiveness are cognitive ability, personality attributes, and educational background.

Macey and Schneider's (2008) review of the engagement literature and subsequent conceptualization of the construct suggests that work engagement reflects the dispositions (feelings of energy) that lead to engaged behaviours (acting in an energetic fashion). Engagement reflects motivational forces (e.g., intrinsic reasons for behaviour), but is conceptually distinct from these forces and from the ensuing behaviour.

Theories of teaching and learning have long emphasized the important role teachers play in supporting students' development in areas beyond their core academic skill. For example, in their conceptualization of high-quality teaching, Pianta and Hamre (2009) describe a set of emotional supports and organizational techniques that are equally important to learners as teachers' instructional methods. They posit that, by providing emotional support and a predictable, consistent, and safe environment, teachers can help students become more self-reliant, motivated to learn, and willing to take risks. Further, by modeling strong organizational and management structures, teachers can help build students' own ability to self-regulate. Content-specific views of teaching also highlight the importance of teacher behaviors that develop students' attitudes and behaviors in ways that may not directly impact test scores. 
Table 10. Differences in teaching effectiveness among the faculty grouped according to certain identified categories

\begin{tabular}{lccccc}
\hline Sources of & $\begin{array}{l}\text { Sum of } \\
\text { Variation }\end{array}$ & $\mathrm{df}$ & $\begin{array}{l}\text { Mean } \\
\text { Square }\end{array}$ & $F$ & Sig. \\
\hline Length of Teaching Experience & & & & & \\
Between Groups & 0.311 & 2 & 0.155 & 0.768 & 0.466 \\
Within Groups & 27.477 & 136 & 0.202 & & \\
Total & 27.787 & 138 & & & \\
& & & & & \\
Academic Rank & 1.491 & 3 & 0.497 & 2.552 & 0.058 \\
Between Groups & 26.296 & 135 & 0.195 & & \\
Within Groups & 27.787 & 138 & & & \\
Total & & & & & \\
& & & & & \\
Educational Qualification & 1.287 & 2 & 0.644 & $3.303^{*}$ & 0.040 \\
Between Groups & 26.500 & 136 & 0.195 & & \\
Within Groups & 27.787 & 138 & & & \\
Total & & & & & \\
& & & & & \\
College Affiliation & 0.941 & 4 & 0.235 & 1.175 & 0.325 \\
Between Groups & 26.846 & 134 & 0.200 & & \\
Within Groups & 27.787 & 138 & & & \\
Total &
\end{tabular}

${ }^{*} p<.05$

Relationships among faculty work engagement and teaching effectiveness. The Pearson's $r$ results in Table 11 revealed that a significant relationship existed between faculty work engagement and teaching effectiveness $(r=.734, p=.000)$. Employing the Coefficient of Determination an $r^{2}$ value of 0.539 was obtained. This explains that $53.9 \%$ of the variations in teaching effectiveness could be attributed to work engagement.

Table 6

Table 11. Relationship of faculty engagement, motivation and teaching performance

\begin{tabular}{lcccc}
\hline Variables & \multicolumn{1}{c}{$\frac{1}{r r^{2} r \text { prob }}$} & & $\frac{2}{r \mathrm{r}^{2} r \text { prob }}$ \\
\hline Faculty Engagement & $-0.734^{*}$ & 0.539 & 0.000 \\
Teaching Effectiveness & - & - & - & - \\
\hline${ }^{*} p<.001$
\end{tabular}

Results of the study is in line with the theory of employee engagement which states that leaders of an organization must ensure that all their staff members are fully engaged, that they are fully switched on at their jobs. Being engaged simply means that one is fully involved and interested in the work so that it really holds his or her attention and inspires him or her to do his or her best (Awaragroup.com, 2012)

Results supports the study of Harris and Rutledge (2007) which concluded that the predictors of teacher quality and effectiveness are cognitive ability, personality attributes, and educational background. 


\section{FINDINGS}

The study found out that 1) The faculty were engaged in their work. 2)They were effective as teachers. 3) The faculty did not differ significantly in their work engagement when classified according to length of teaching experience, academic rank, educational qualification and college affiliation. 4)Significant differences were noted in teaching effectiveness among the faculty classified according to educational qualification.No significant differences were noted in teaching effectiveness among the faculty classified according to length of teaching experience, academic rank, and college affiliation. 5) Significant relationship existed between faculty work engagement and teaching effectiveness.

\section{CONCLUSIONS}

In view of the findings of the study, the following conclusions were drawn 1) The faculty in a state institution of higher learning in this research appear to possess high levels of performance and a drive for efficiency. They seem to have a clear understanding about the desired outcomes of their roles. Likewise they appear to project an emotional commitment to what they do, to their organization, work group, and job. As a result, they are satisfied with their jobs, feel valued, and experience collaboration and trust. Perhaps, these faculty will stay in the company longer and continually find smarter, more effective ways to add value to the institution 2) The faculty in a state institution of higher learning in this research appear to exert sufficient effort to achieve their goals in teaching. It seems indicative that, on their part, the faculty produce results that are wanted, enough to satisfy the intended effect or outcome of teaching. 3) Length of teaching experience, academic rank, educational qualification, and college affiliation were factors found not to influence the faculty work engagement.Hence, regardless of whether one has 10 years and below, 11 to 20 years, or above 20 years stint in teaching; had academic rank of instructor, assistant professor, associate professor, or professor; had baccalaureate, master's, or doctorate degree; or affiliated with colleges of management, teacher education, information technology, agriculture or maritime, their work engagement remains the same.4)Educational qualification is a factor found to significantly influence one's teaching effectiveness. As revealed in the findings, those with doctorate degrees were significantly more effective compared with those with master's degrees.It seems apparent that having a higher degree, enables one to become more effective in teaching, as in the case of the faculty in a state institution of higher considered in this research. It may therefore be construed, that, the more training one has, especially earning a higher degree, the more effective one becomes in teaching, as in the case of the faculty in a state institution of higher learning in this research.Length of teaching experience, academic rank and college affiliation were factors found not to significantly influence one's teaching effectiveness. Hence, regardless of whether one has 10 years and below, 11 to 20 years, or above 20 years teaching experience; had academic rank of instructor, assistant professor, associate professor, or professor; or affiliated with colleges of management, teacher education, information technology, agriculture or maritime, their teaching effectiveness remains the same. 5)Work engagement is also a factor found to positively and significantly affect one's teaching effectiveness. It appears that, if one is engaged in his or her work, one's teaching effectiveness is high. Satisfied with one's job, feel valued, experience collaboration and trust produce result that is wanted -- a clear indication of doing and liking a job to meet one's goal and objectives, more significantly in teaching.

\section{RECOMMENDATIONS}

Based on the findings and conclusions of this study, the following recommendations are advanced: 1)Administrators may extend support to the faculty by organizing seminar-workshop to further improve the faculty level of work engagement and teaching effectiveness.2)The teachers in a state institution of higher learning shall attend training on faculty development and other seminars to equip themselves of the latest technological trend necessary to advance their teaching. 3)Human resource management officershould update their faculty development plan to include training for faculty in the area of work engagement and teaching effectiveness. 4)Students should take part in evaluation of their teachers and suggest ways to improve their teaching-learning process. 5)Researchers may correlate their study on faculty work engagemen and teaching effectiveness in private higher education institution. 


\section{REFERENCES}

Aypay, A. (2011). Behavioral habits of primary and secondary teachers and their perceptions on the characteristics of a "good teacher". Ilköğretim Online, 10(2), 620-645.

Awaragroup.com. The theory of employee engagement. Retrieved from https://www.awaragroup.com/blog/thetheory-of-employee-engagement/

Barry, R. A. (2010). EFL teachers' creativity and their teaching's effectiveness: A structural equation modelling approach. International Journal of Instruction, 11(1), 227-238

Başaran, M., \& Dedeoğlu Orhun, B. (2013). Factors affecting the preservice teachers'professional motivation. İnönü Üniversitesi Eğitim Fakültesi Dergisi, 14(3),129-151.

Borkar, U. A. (2013). A study of teacher effectiveness of secondary school teachers inrelation to teacher stress. International Journal of Humanities and Social Science Invention, 2(12), 13-16.

Cherwin, K. (2016). Faculty engagement: Lessons learned from three institutions. Retrieved from https://www.higheredjobs.com/articles/default.cfm?auth=30\&bd $=8 \% 23768 \% 231366 \% 231 \% 23 \mathrm{n}$

Colbeck, C.L., \& Michael, P.W. (2006). The public scholarship: Reintegrating Boyer's four domains. In J.M. Braxton (Ed.), Analyzing faculty work and rewards: Usin Boyer's four domains of scholarship (pp. 719).

Emery, C. R., Kramer, T. R., \& Tian, R. G. (2003). Return to academic standards: Acritique of students' evaluations of teaching effectiveness. Quality assurancein education: An international perspective, 11(1), 37-47.

Evans, E. D. (2006). Transition to teaching. New York: Holt, Rinehart and Winston.

Fraenkel, J., \& Wallen, N. (2009). How to design and evaluate research 7th Edition. New York: McGraw-Hill

Garrett, R., \& Steinberg, M. (2015). Examining teacher effectiveness using classroom observation scores: Evidence from the randomization of teachers to students. Educational Evaluation and Policy Analysis, $37,224-242$.

Gupta, M., Ganguli, S. \& Ponnam, A. (2015), Factors affecting employee engagement in India: A study on offshoring of financial services. The Qualitative Report, 20(8), pp. 498-515.

Harris, D. N., \& Rutledge, S. A. (2007). Quality and performance among experienced teachers in Malaysia. Australian Journal of Teacher Education 2012, 37(11).

Macey, W. H., \& Schneider, B. (2008). The meaning of employee engagement. Industrial and Organizational Psychology, 1, 3-30.

Margolis, S. (2018). Employee engagement survey question. Retrieved from https://lattice.com/library/28employee-engagement-survey-questions-you-need-to-ask

Mishra, S. (2012). Teacher effectiveness questionnaire. Retrieved from https://shodhganga.inflibnet.ac.in/bitstream/10603/7871/12/12_annexture.pdf

Paolini, A. (2015). Enhancing teaching effectiveness and student learning outcomes. The Journal of Effective Teaching, 15(1), 20-33.

Rhoades, G.(2012). Faculty engagement to enhance student attainment. Paper prepared for National Commission on Higher Education Attainment Center for the Study of Higher Education, University of Arizona.

Pianta R.C., \& Hamre B.K. (2009). Conceptualization, measurement, and improvement of classroom processes: Standardized observation can leverage capacity. Educational Researcher, 38(2);109-119.

Sahan, G. (2016). ) Analysis of the problems encountered in education of teachersand solution recommendations in accordance with the opinions of faculty of education students. International Journal of Environmental \& Science Education, 2016, 11(5), 1055-1064.

Sandmann, L. R., Thornton, C. H., \& Jaeger, A. J. (Eds.) (2009). Institutionalizing community engagement in higher education: The first wave of Carnegie classified institutions. New directions for higher education, 147. San Francisco: Jossey-Bass/Wiley. 
Schaufeli W. B., Bakker A. B. (2010). Work and well-being. Towards a positive approach in occupational health psychology, Gedrag \&Organizatie, 14(5), 229-253.

Shuck, B. (2011). Four emerging perspectives of employee engagement: An integrative literature review. Human Resource Development Review, 10, 304-328.

Sobrero, P., \& Jayaratne, K. (2014). Scholarship perceptions of academic department heads: Implications for promoting faculty community engagement scholarship. Journal of Higher Education Outreach and Engagement, 18(1), 123-151.

Yen, K. L., \& Hsu, M. W. (2012). A study on the relationship among junior high school teachers' orientations to happiness, teachers' subjective well-being and teachers' organizational commitment. Journal of Pingtung University of Education, 38, 93-126.

\section{Sample Instrument}

\section{APPENDIX}

\section{Employee Engagement Survey Question}

Instruction: Please rate to what extent do you agree or disagree with each of these statements.by placing a check (/) mark coresponding to your choice. Your choices are:

SD - Strongly Disagree D - Disagree N - Neutral A - Agree SA - Strongly Agree

\begin{tabular}{|c|c|c|c|c|c|c|}
\hline No. & Statements & SD & $\mathrm{D}$ & $\mathrm{N}$ & A & SA \\
\hline 1. & The purpose of this organization is meaningful to me. & & & & & \\
\hline 2. & $\begin{array}{l}\text { The values of this organization are consistent with my } \\
\text { values. }\end{array}$ & & & & & \\
\hline 3. & $\begin{array}{l}\text { I understand how my work contributes to the } \\
\text { organization's performance. }\end{array}$ & & & & & \\
\hline 4. & I am doing the right work for me. & & & & & \\
\hline 5. & I trust senior leaders. & & & & & \\
\hline 6. & I trust my immediate supervisor. & & & & & \\
\hline 7. & $\begin{array}{l}\text { Senior leaders are fair, or I am treated with fairness in } \\
\text { this organization. }\end{array}$ & & & & & \\
\hline 8. & My immediate supervisor is fair. & & & & & \\
\hline 9. & Senior leaders are honest. & & & & & \\
\hline 10. & My immediate supervisor is honest. & & & & & \\
\hline
\end{tabular}

\section{Teacher Effectiveness Questionnaire}

Instruction: You are requested to read the statement and answer truly and frankly each statement in the following ways. Please $(\sqrt{ })$ tick against the selected answer. Your choices are:

SD - Strongly Disagree D - Disagree U - Undecided A - Agree SA - Strongly Agree

\begin{tabular}{|l|l|l|l|l|l|l|}
\hline No. & Statement & SD & D & U & A & SA \\
\hline 1. & $\begin{array}{l}\text { I have full authority on the subject I am } \\
\text { teaching. }\end{array}$ & & & & & \\
\hline 2. & $\begin{array}{l}\text { Besides my teaching subject, I have the ability to } \\
\text { teach other needed subjects like current events, } \\
\text { general knowledge etc. }\end{array}$ & & & & & \\
\hline 3. & $\begin{array}{l}\text { I advice the students to solve their problems } \\
\text { according to their needs. }\end{array}$ & & & & \\
\hline 4. & $\begin{array}{l}\text { I give due opportunities to the students for } \\
\text { proper motivation. }\end{array}$ & & & & \\
\hline 5. & $\begin{array}{l}\text { I use more rewards and lesser punishment in the } \\
\text { classroom for achievement of desired aims. }\end{array}$ & & & & \\
\hline
\end{tabular}

